\title{
William HARMLESS SJ, Desert Christians. An Introduction to the Literature of Early Monasticism, Oxford 2004, University Press, ss. XXV + 488.
}

Książkę napisał amerykański jezuita, profesor teologii w Creighton University w Omaha, w stanie Nebraska. Jest on ponadto autorem monografii Augustine and the catechumenate (Collegeville Minn. 1995) oraz szeregu publikacji na temat wczesnego monastycyzmu w znanych periodykach teologicznych: „Theological Studies”, „Church History” i „Studia Patristica”. Zgodnie z założeniem zawartym w podtytule, Desert Christians jest wprowadzeniem do literatury wczesnego monastycyzmu. W swojej treści jest jednak czymś więcej niż tylko wprowadzeniem. Stanowi swoistą monografię, ukazującą nie tylko bardziej charakterystyczne wątki teologiczne dla literatury monastycznej środowiska egipskiego, ale i panoramę geograficzną, historyczną, kulturową, polityczną i kościelną dla tej literatury. Łączy w sobie charakter naukowo-badawczy i popularyzatorski. Można więc tę pozycję zakwalifikować do rangi podręczników o zawężonej dziedzinie, która da się wyrazić w następujących kluczowych hasłach: historia - historia Kościoła - patrologia - monastycyzm literatura wczesnochrześcijańska - Ojcowie Pustyni. Formalnie, rolę podręcznika pozycja ta może pełnić na kierunku teologii, w dziedzinie patrologii, bądź też historii duchowości, czy też - wychodząc szerzej - religioznawstwa. Zgodnie z głównym tytułem dzieła, autor zajmuje się fenomenem ruchu monastycznego na egipskiej pustyni, otwierającym historię chrześcijańskiego monastycyzmu w ogóle.

W pierwszej części (I. „The World of Early Monasticism”) przedstawia w wymienionych wyżej aspektach tło dla wspomnianego ruchu (1. „Roman Egypt”, 2. „Patriarchs, Councils and Controversies 300-451”), w kolejnych częściach prezentuje trzy główne rozdziały w historii egipskiego monastycyzmu i myśli monastycznej (II. „Antony and Pachomius”, III. „The Desert Fathers”, IV. „Monastic Theologians”. Ostatnią V część (Reflections, Monastic origins: perspectives, Discoveries and disputed questions) poświęca kontrowersjom teologicznym i kościelnym w łonie egipskiego i częściowo pozaegipskiego monastycyzmu.

Praca ma duży walor dydaktyczny. Autor ujmuje zjawisko wczesnego ruchu monastycznego w Egipcie w sposób integralny, nie pomijając żadnego z głównych jego elementów. Główny aspekt spojrzenia ma charakter patrystyczny i teologiczny. Autor wydobywa nade wszystko wątki teologiczne myśli monastycznej, w oparciu o jej podstawowe źródła. Wykazuje się, nie tylko w zestawieniu obszernej bibliografii, ale i w analizie, dużą znajomością źródeł. Często i chętnie cytuje wypowiedzi Ojców Pustyni, co pozwala czytelnikowi obcować bezpośrednio z ich myślą. Starannie wybiera bardziej lapidarne i oryginalne myśli czy relacje, tak iż czytelnik nie ulega znużeniu przy ich lekturze. Poza klasyką literatury w tym względzie, korzysta w wyników nowszych badań 
egipskich papirusów. Wyjaśnia wiele pojęć z zakresu monastycyzmu, niezrozumiałych dla współczesnego czytelnika (np. anachoreza, s. 64). Stara się przedstawić ich sposób myślenia, odwołując się do ich własnych wypowiedzi, przez co unika błędu pewnej stronniczości. Interesuje go nade wszystko to, co Ojcowie Pustyni myśleli o życiu duchowym i jaką drogę proponowali w realizacji swoich ideałów. Przekazuje ogrom wiedzy encyklopedycznej: faktograficznej, historycznej, leksykologicznej etc. Unika przytaczania oczywistości. Pracę czyta się z ogromnym zaciekawieniem, bo otwiera ona przed czytelnikiem bogaty świat egipskich mnichów.

Wyjątkowo cenny jest ostatni rozdział, w którym amerykański badacz pokazuje napięcia w ruchu monastycznym, głównie na podłożu teologicznym. Przez wieki dominowało ujęcie hagiograficzne życia, działalności i pisarstwa Ojców Pustyni, dlatego że ich literatura była nade wszystko w użytku pobożnościowym i konfesyjnym. Nasze czasy pozwoliły naukom teologicznym zdobyć większą autonomię i, wyposażając w bogatsze środki badawcze, zwróciły je ku większemu naukowemu obiektywizmowi. Harmless ukazuje, że środowisko mnichów wstrząsane było od początku wewnętrznymi sporami. Obok anachoretów Antoniego Pustelnika i cenobitów Pachomiusza, byli zdawkowo wspominani w zachowanych źródłach monastycznych apotaktikoi, asceci mieszkający w bezpośrednim pobliżu zamieszkałych osad, krytykowani nieraz przez pustynnych mnichów. Szerokie wpływy miał u egipskich mnichów, zwłaszcza pochodzenia greckiego, orygenizm, wokół którego spór stał się jedną z formalnych przyczyn wypędzenia pustelników z osady w Kellia przez biskupa Teofila Aleksandryjskiego. Mnichów dotknęła również tzw. melecjańska schizma, powstała w zamęcie okresu prześladowań i atmosferze wzajemnych oskarżeń o apostazję podczas cesarskich represji. Pewną alternatywę dla chrześcijańskiego monastycyzmu stanowił ascetyzm manichejski, któremu urokom przez pewien czas ulegał m. in. Augustyn z Hippony. Harmless opisuje kilka takich napięć w środowiskach monastycznych, rzadko ujmowanych w klasycznych podręcznikach ruchu monastycznego.

We wstępie do swojej pracy autor zaznacza, że jego dzieło nie jest pierwsze, które panoramicznie ujmuje badane zjawisko. Znane mu są takie prace popularyzatorskie, jak: D. Burton-Christie - The Word in the Desert (New York 1993), G. Gould - The Desert Fathers on Monastic Community (New York 1993), J. Goehring - Ascetics, Society and the Desert (Harrisburg 1999) oraz publikacje najwybitniejszych znawców w tej dziedzinie, jak: I. Hausherr, A. Guillaumont, A. de Vogüé, L. Regnault i inni. Chociaż Harmless nie wyjaśnia, jak się ma jego praca do powyższej literatury, to jednak należy ogólnie dodać, że wyżej wymienieni autorzy podejmują interesującą nas kwestię w sposób węższy, skupiając się na pewnych szczegółowych wątkach monastycyzmu, bądź też traktują ruch pustelniczy na pustyni jako jedną z form monastycyzmu. Zakres i charakter pracy Harmlessa, o ile się orientuję, pokrywa się 
jedynie z pracą D. Chitty - The Desert a City, (Oxford 1966, ss. 222). Istnieje więc zatem już pewna tradycja tego renomowanego ośrodka w edycji prac naukowych o pustelniczym ruchu w Egipcie. Harmless sam ustosunkowuje się do dzieła swego poprzednika, które nazywa ,a work of genius” (s. X). Praca Chittyego, wybitnego znawcy naszej kwestii, zdaniem Harmlessa, zawiera tak skondensowaną wiedzę o mnichach na pustyni, że wydaje się być zbyt trudna dla czytelników początkujących w tego rodzaju lekturze. Ponadto Chitty poświęca tylko siedemdziesiąt stron Egiptowi. Stwierdzamy nie tylko odwołując się do opinii Harmlessa, ale i na podstawie lektury jego dzieła, że omawiana przez nas monografia jest bardziej wyczerpującą prezentacją egipskiego monastycyzmu i posiada większe walory dydaktyczne niż Chittyego. Zresztą, najkorzystniej byłoby wydać w języku polskim obie te publikacje. Nie ulega wątpliwości, że byłyby one bardzo cennym uzupełnieniem pewnej luki w tym zakresie w polskojęzycznej literaturze.

Nie dysponujemy w języku polskim pracą, która by w sposób podręcznikowy wprowadziła nas w historię i teologię ruchu pustelniczego w Egipcie. Mamy wprawdzie monografię M. Kaniora - Historia monastycyzmu chrześcijańskiego, t. 1. Starożytność (Kraków 1993, ss. 398), ale dzieło to z założeń ukierunkowane na prezentację całości monastycyzmu, Egiptowi poświęca jedynie jedną czwartą tomu; nie ma tam też gruntowniejszej prezentacji myśli teologicznej: ponieważ autor skupia się na historii ruchu, więc jego publikacja obejmuje bardziej zakres historii Kościoła niż patrologii. Natomiast książka R. Przybylskiego - Pustelnicy i demony (Kraków 1994), należy do dziennikarskiej i bardzo subiektywnej eseistyki. Tak więc dzieło Harmlessa stanowiłoby pierwszą popularnonaukową monografię poświeconą sensu stricto zagadnieniu wczesnochrześcijańskiego ruchu monastycznego w Egipcie.

\section{Leon Nieścior OMI - Poznań, UAM}

\section{Ks. Stanisław JÓŹWIAK, Państwo i Kościót w pismach św. Augustyna, Lu- blin 2004, Wydawnictwo KUL, ss. 235.}

Życie chrześcijanina rozgrywa się na skrzyżowaniu, na którym dochodzi do spotkania dwóch zupełnie różnych rzeczywistości - państwa i Kościoła. Jest on jednocześnie obywatelem konkretnego kraju, mającym wobec niego rozmaite obowiązki moralne lub prawne, ale jednocześnie należy do wspólnoty, która, będąc w swej istocie rzeczywistością Bosko-ludzką, wykracza poza doczesne „tu i teraz”. Chrześcijanin trwa więc w swoistym napięciu pomiędzy byciem w świecie, a byciem już „nie z tego świata”. Taka sytuacja sprawia, że zagadnienie relacji pomiędzy Kościołem a państwem staje się przedmiotem zarówno badań naukowych, jak i konkretnych rozwiązań prawnych dotyczących obu 